Preprints of the

Max Planck Institute for

Research on Collective Goods

Bonn 2015/5

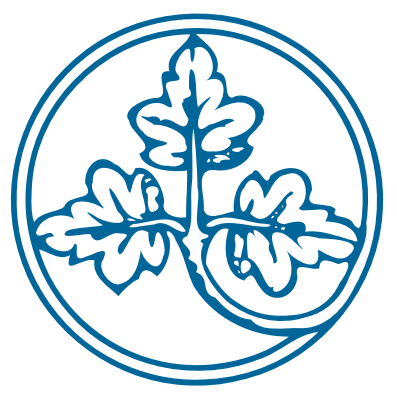

Customary International Law and Public Goods

Niels Petersen

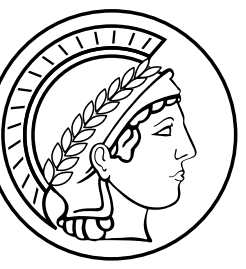




\title{
Customary International Law and Public Goods
}

\author{
Niels Petersen
}

February 2015 


\title{
Customary International Law and Public Goods*
}

\author{
Niels Petersen ${ }^{\#}$
}

\section{Introduction}

The protection of global public goods is one of the most pressing challenges we are facing today. ${ }^{1}$ The mitigation of climate change is the most prominent example. ${ }^{2}$ In the next decades, global warming is feared to cause rising sea levels, melting ice and snow, increasing precipitation, extreme weather events, and widespread coastal flooding. By now, it has been almost universally recognized that these climate changes are at least influenced by human action. ${ }^{3}$ Since the early 1990s, the international community has, in principle, recognized this challenge. In 1992, the United Nations Framework Convention on Climate Change (UNFCCC) was concluded at the end of the Rio summit. It has been ratified by 196 parties.

While there are only two international treaties, the Vienna Convention for the Protection of the Ozone Layer and the corresponding Montreal Protocol, which have more ratifications than the UNFCCC, the effectiveness of the Framework Convention has been limited. In the Kyoto Protocol, which was adopted in 1997 and entered into force in 2002, the states agreed for the first time on concrete targets for the reduction of greenhouse gas emissions. Nevertheless, the Kyoto obligations have often been criticized as too modest. ${ }^{4}$ But even these modest targets have failed to prevent the significant increase in greenhouse gas emissions during this centu-

* Book chapter for CUSTOM'S FUTURE: INTERNATIONAL LAW IN A CHANGING WORLD (Curtis A. Bradley ed., forthcoming Cambridge University Press)

\# $\quad$ Professor of Public Law, International Law and EU Law at the University of Münster; Research Associate at the Max Planck Institute for Collective Goods, Bonn. I am very grateful to Curtis Bradley, Christoph Engel, Mitu Gulati, Leonard Hoeft, Anna Kochanova, Brian Lepard, Christian Willmes, and Ingrid Wuerth for valuable comments on previous drafts of this paper.

1 See Curtis A. Bradley \& Mitu Gulati, Withdrawing from International Custom, 120 YALE L. J. 202,264 (2010).

2 See Alexander Thompson, Rational design in motion: Uncertainty and flexibility in the global climate regime, 16 EuR. J. INT'L REL. 269, 269-70 (2010); Joel P. Trachtman, Persistent Objection, Cooperation, and the Utility of Customary International Law, 21 DukE J. Comp. \& INT'L L. 221, 223 (2010); Nico Krisch, The Decay of Consent: International Law in an Age of Global Public Goods, 108 AM. J. INT’L L. 1,15 (2014).

3 See Climate Change 2013: The Physical Science Basis. Working Group I: Contribution to the Fifth Assessment Report of the Intergovernmental Panel on Climate Change (Thomas F. Stocker et al. eds., 2013). See also Jody Freeman \& Andrew T. Guzman, Climate Change and U.S. Interests, 109 COL. J. TRANSNAT'L L. 1531, 1544-45 (2009) with further references.

4 See JutTa Brunnée \& Stephen J. ToOpe, Legitimacy AND Legality in InTERnAtionAL LAW 137 (2010); Thompson, supra note 2, at 277. But see also Charlotte Streck, Innovativeness and Paralysis in International Climate Policy, 1 TRANSNAT’L ENV. L. 137, 142-51 (2012) (pointing out innovations of the Kyoto Protocol). 
ry. ${ }^{5}$ Major actors, such as the United States, have not ratified the Kyoto Protocol, while other states have failed to comply with their reduction goals.

Therefore, progress in establishing a cooperative framework for tackling climate change can, at best, be described as very slow. ${ }^{6}$ Some authors have suggested that treaty mechanisms might not be the optimal instrument for climate regulation, as they involve high decisionmaking costs. ${ }^{7}$ Instead, they propose customary international law as an alternative, which might, due to its flexibility, be better suited to the achieve the regulatory goals. ${ }^{8}$

This paper aims to examine this hypothesis. It explores the potential of customary international law to contribute to the protection of global public goods. The analysis proceeds in the three steps. First, it will have a closer look at the concept of public goods and common pool resources. Economic theory predicts that public goods are usually underprovided and common pool resources overexploited. ${ }^{9}$ Experimental evidence confirms the general trend, even though the level of contributions is higher than economic theory predicts. Most individuals are not purely self-interested free-riders, but conditional cooperators who are willing to contribute if everybody else contributes.

On this basis, the second section examines the formation of customary international law. The analysis shows that sustaining cooperation in multilateral settings through customary law is difficult. With regard to the mitigation of climate change, it is unlikely that states will coordinate on an equilibrium that will lead to a reduction of greenhouse gas emissions. The section then examines two further ways of identifying customary international law through moral interpretation and judicial lawmaking. However, the potential of these two avenues to protect global public goods effectively is rather limited.

The final section analyzes the protection of global public goods through the initially unilateral extension of authority. One problem of global public goods is that states have shared authority over them. A solution might be to divide authority by extending the jurisdiction of the nation states. I will draw from an example from the protection of common pool resources: the protection of fish stocks through the extension of the exclusive economic zone to 200 miles. In a

5 David G. Victor, Global Warming Gridlock: Creating More Effective Strategies for Protecting the Planet 3 (2011). See also Sujata Gupta \& Dennis A. Tirpak, Policies, Instruments and Cooperative Arrangements, in Climate Change 2007: Mitigation. Contribution of Working GrouP III to the Fourth Assessment Report of the Intergovernmental PANel on Climate Change 745 (Bert Metz, Ogunlade Davidson, Peter Bosch, Rutu Dave \& Leo Meyer eds., 2007) (with further references).

$6 \quad$ Streck, supra note 4, at 139.

7 Scott Sullivan, Networking Customary Law, 61 KAN. L. REV. 659, 662-65 (2013).

8 Pierre-Marie Dupuy, Formation of Customary International Law and General Principles, in THE OXFORD HANDBOOK ON INTERNATIONAL ENVIRONMENTAL LAW 449, 463-65 (Daniel Bodansky, Jutta Brunnée \& Ellen Hey eds., 2008); Sullivan, supra note 7, at 661-68 (making special reference to international negotiations on climate change). See also Francesco Parisi, Toward a Theory of Spontaneous Law, 6 CONST. POL. ECON. 211, 214 (1995) (arguing that “processes of individual and social adaptation” may still work when explicit bargaining is unlikely to occur or too costly).

9 Katharina Holzinger, Common Goods, Matrix Games and Institutional Responses, 9 EUR. J. INT'L REL. 173, 176 (2003). 
second step, I will analyze whether this example contains any lessons for the mitigation of climate change.

\section{The Concept of Public Goods and of Common Pool Resources}

\section{Public goods as an economic concept}

Traditionally, public goods are characterized by two properties: non-excludability and nonrivalry in consumption. ${ }^{10}$ This means that nobody can be excluded from using the good, and the quality and the availability of the good does not depend on the number of people using it. The classic example is national defense. The existence and the quality of an army do not depend on the number of people who are living in the territory defended by the army. Furthermore, no person living in the defended territory can be excluded from the protective effect of the army. Other examples are lighthouses, street lighting, fresh air, or the ozone layer. Public goods have positive externalities and thus give incentives to free-ride. For each individual, it is rational not to contribute to the provision or maintenance of a public good and to hope that other members of the community will finance it. If four roommates in a shared apartment decide on whether to buy a shared TV, each roommate may want to understate the utility of the TV. Once the other three have bought the TV for the common space, it would be difficult to exclude the fourth member from using it even though she has not contributed. However, if every roommate understates her utility, it is less likely that the TV will be bought in the end. Therefore, market mechanisms provide fewer public goods than would be economically efficient. $^{11}$

Some public goods have the opposite problem: Their use does not create positive, but negative external effects. These goods are often called "public bads". The primary example of a public bad is the pollution of the atmosphere. Nobody can be excluded from polluting the atmosphere and one's ability to pollute does not depend on whether other people are polluting as well. In effect, public bads are the mirror image of public goods and can thus be modeled in the same way as the latter. We formulate the above example in a positive way and talk of the protection of clean air instead of the pollution of the atmosphere, which would transform the problem from one of preventing a public bad to one of maintaining a public good.

Finally, there are goods that are usually called common goods or common pool resources. With public goods, they share the characteristic that nobody can be excluded from using them; but there is rivalry in consumption. The use of a common pool resource diminishes its quality and decreases its availability. Garret Hardin has shown in his classic contribution on

10 Richard CORNes \& TODd SANDLER, THE THEORY OF EXTERNALITIES, PUBliC GOODS, AND CLUB GOODS 144-45 (2 ed. 1996); Holzinger, supra note 9, at 176. See also the seminal contribution of Paul A. Samuelson, The Pure Theory of Public Expenditure, 36 REv. Econ. \& STAT. 387 (1954) (focusing on the nonrivalry of consumption).

11 Seminally, Mancur Olson, The Logic of Collective Action: Public Goods and the Theory of GROUPS (1965). 
the tragedy of the commons that such shared resources are usually overexploited. ${ }^{12}$ Every individual who uses a common pool resource obtains the full benefit of the use, while the costs of the use are socialized in that they are borne by the entirety of the potential users. Examples for common pool resources are global fish stocks or other natural resources. The border between public goods and common pool resources is more salient in theory than in practice. Usually the incentive structure is the same: Public goods are underprovided and common pool resources are overexploited. ${ }^{13}$

In the context of the nation state, this problem is often met through public regulation. National defense, lighthouses, and street lighting are financed through taxes. Every taxpayer has to contribute to the provision of the public good, regardless of the extent to which she values it. In other cases, the external effects of public goods are internalized through regulatory measures. One example is knowledge, which is protected through copyrights and patents. These measures do not limit the access to knowledge, but their commercial use. Negative external effects that occur through the use of common pool resources are reduced through regulation and taxation of certain conduct. A measure that requires factories to limit their emissions of polluting substances aims at reducing the social costs of private production processes. In turn, imposing taxes on gasoline is a way to internalize the social costs of driving.

However, regulatory measures that aim at the provision of public goods and the protection of common goods against overexploitation are not easily available on the international plane. This is problematic if the scale of a specific public good transgresses the border of a nation state. The incentive structure for the mitigation of climate change is, basically, the same as for the provision of national defense. The decisive difference is the scale of the problem. While national defense can effectively be provided through public regulation on the nation state level, climate change is a global problem. Greenhouse gas emissions not only affect the climate on a specific territory, but they affect the global climate. Consequently, national legislatures often do not have incentives to internalize costs through public regulation.

On the international level, there is no central legislature that could impose taxes to finance the provision of a global public good. Certainly, states can coordinate to provide jointly for the public good. However, in such a situation, we reencounter the free-rider problem. As contributions to the public good are costly, every state has incentives to understate its own utility. ${ }^{14}$ The same applies to the reverse situation of protecting common pool resources. If the individ-

12 Garrett Hardin, The Tragedy of the Commons, 162 SCIENCE 1243 (1968).

13 External effects do not necessarily lead to market inefficiencies. Ronald Coase has shown in a seminal article that trade can resolve the matter effectively if there are no transaction costs, see Ronald $\mathrm{H}$. Coase, The Problem of Social Cost, 3 J. L. \& ECON. 1 (1960). However, contracting about public goods and common pool resources often entails significant transaction costs because of the amount of affected people, so that a Coaseian bargaining solution does not work. On the latter, see Alexander Morell, Demand, Supply, and Markets, in ECONOMIC METHODS FOR LAWYERS (Emanuel Towfigh \& Niels Petersen eds., forthcoming 2015).

14 However, public goods may be provided if one state has such a high interest in the provision of the public good that its benefits outweigh the costs, see Christopher Bliss \& Barry Nalebuff, Dragon-slaying and ballroom dancing: The private supply of a public good, 25 J. PUBL. ECON. 1 (1984). 
ual benefits obtained by a national economy from using a shared resource are higher than the costs that are imposed on the economy, states have incentives not to impose regulation against overexploiting the resource. The use of common pool resources is thus often not regulated, even if their use has socially detrimental effects on the global level.

\section{Experimental evidence}

Since the 1970s, there has been extensive experimental research on the predictions of economic theory regarding public goods and the conditions under which public goods are provided through cooperation. ${ }^{15}$ Public goods experiments are usually played in groups of at least four participants. These participants get a certain initial endowment and have the choice between either keeping their endowment or contributing all or part of it to a specific public good. The money that is contributed to the public good is multiplied by a factor $\mathrm{x}$ that is greater than 1 , but smaller than the number of players, and then equally distributed among all players.

If all players contribute all of their endowment to the establishment of the public good, the overall payoff is higher than if everybody keeps her endowment and contributes nothing. Contributing to the public good is thus the socially optimal solution. Individually, however, it is rational to keep the endowment because everybody receives a payoff of less than 1 for each unit contributed to the public good. ${ }^{16}$

The main finding of the early public goods experiments was that contributions to the public good are higher than would be expected by economic theory. ${ }^{17}$ On average, players contribute between 40 to $60 \%$ of the socially optimal level. ${ }^{18}$ However, there is a steady decline in cooperation over time. ${ }^{19}$ Early attempts to explain this observation have found that participants are not only guided by pure self-interest, but that most of them base their contributions on fairness considerations even though the individual fairness norms may vary. ${ }^{20}$ A closer look roughly distinguishes several types of participants. ${ }^{21}$ Only a minority of participants are free-

15 For a review of the experimental literature, see John. O. Ledyard, Public Goods: A Survey of Experimental Research, in THE HANDBOOK OF EXPERIMENTAL ECONOMICS 111 (John H. Kagel \& Alvin E. Roth eds., 1995); Ananish Chaudhuri, Sustaining cooperation in laboratory public goods experiments: a selective survey of the literature, 14 EXP. ECON. 47 (2011).

16 See Christoph Engel \& Michael Kurschilgen, The Coevolution of Behavior and Normative Expectations: An Experiment, 15 AM. L. \& ECON. REV. 578, 579 (2013).

17 See, e.g., Gerald Marwell \& Ruth E. Ames, Experiments and the Provision of Public Goods: I. Resources, Interest, Group Size, and the Free-Rider Problem, 84 AM. J. Soc. 1335 (1979); Vernon L. Smith, Experiments with a Decentralized Mechanism for Public Good Decisions, 70 AM. ECON. REV. 584 (1980); Elinor Ostrom, James Walker \& Roy Gardner, Covenants with and without a Sword: Self-Governance is Possible, 86 AM. POL. SC. REV. 404 (1992).

18 Matthew Rabin, Incorporating Fairness into Game Theory and Economics, 83 AM. ECON. REV. 1281, 1283 (1993); Chaudhuri, supra note 15, at 48.

19 Id. See also Christoph Engel, The Emergence of a New Rule of Customary Law: An Experimental Contribution, 7 REV. L. \& ECON. 767, 773 (2011).

20 Marwell \& Ames, supra note 17, at 1357. For an attempt to model such fairness preferences, see Rabin, supra note 18.

21 See Urs Fischbacher, Simon Gächter \& Ernst Fehr, Are people conditionally cooperative? Evidence from a public goods experiment, 71 ECON. LETTERS 397 (2001). 
riders who are only interested in their own personal gains and never contribute significant amounts to the public good. In contrast, the majority of participants are conditional cooperators. $^{22}$ These conditional cooperators contribute to the public good, as long as others contribute as well. They are happy to advance the common cause, but they do not want to be exploited by the other participants.

For conditional cooperators, cooperation thus depends on their beliefs of whether others will cooperate as well. ${ }^{23}$ These expectations are usually formed by observing the contributions of other participants. ${ }^{24}$ The mean contribution in the first round sets the stage for later rounds: If the group makes high average contributions in the first round, it will continue to make rather high contributions in the following rounds. ${ }^{25}$ However, already a small percentage of freeriders or imperfect conditional cooperators may lead to a decline in average contributions and to the breakdown of cooperation. ${ }^{26}$

One mechanism that is usually proposed to prevent free-riding and imperfect conditional cooperation is decentralized punishment. Several studies show that cooperation is reinforced if individual participants have the ability to punish those participants whose contributions are less than average. ${ }^{27}$ Nevertheless, decentralized punishment mechanisms have two problems. On the one hand, punishment is costly. A punishment mechanism is itself a second-order public good. ${ }^{28}$ Participants will be reluctant to punish free-riders and rather hope that others will implement the costly punishment. Even if this does not mean that there is a total absence of punishment, ${ }^{29}$ the punishment of free-riders will be the harder to maintain the bigger the group size is. With increasing participants, free-riding is more difficult to detect, and the public-good character of the punishment mechanism will become more pronounced. On the other hand, participants may be deterred from punishing free-riders if the latter have means for

22 Claudia Keser \& Frans van Winden, Conditional Cooperation and Voluntary Contributions to Public Goods, 102 SCAND. J. ECON. 23 (2000); Fischbacher, Gächter \& Fehr, supra note 21; Urs Fischbacher \& Simon Gächter, Social Preferences, Beliefs, and the Dynamics of Free-Riding in Public Goods Experiments, 100 AM. ECON. REV. 541 (2010).

23 Martin Dufwenberg \& Georg Kirchsteiger, A theory of sequential reciprocity, 47 GAMES \& ECON. BEHAV. 268 (2004); Armin Falk \& Urs Fischbacher, A theory of reciprocity, 54 GAMES \& ECON. BEHAV. 293 (2006).

24 Fischbacher \& Gächter, supra note 22, at 548-549. See also ElinOR OsTROM, Governing THE COMMONS: THE EVOLUTION OF INSTITUTIONS FOR COLLECTIVE ACTION 183-84 (1990) on the importance of trust and communication for the success of decentralized cooperation.

25 Keser \& Winden, supra note 22, at 32; Engel, supra note 19, at 780-81; Christoph Engel et al., First impressions are more important than early intervention: Qualifying broken windows theory in the lab, 37 INT’L REV. L. \& ECON. 126, 129-30 (2014).

26 See Fischbacher, Gächter \& Fehr, supra note 21, at 403; Fischbacher \& Gächter, supra note 22, at 55054.

27 See Toshio Yamagishi, The Provision of a Sanctioning System as a Public Good, 51 J. PERSONALITY \& Soc. Psych. 110 (1986); Ostrom, Walker \& Gardner, supra note 17; Ernst Fehr \& Simon Gächter, Cooperation and Punishment in Public Goods Experiments, 90 AM. ECON. REV. 980 (2000).

28 Yamagishi, supra note 27, at 111.

29 See Fehr \& Gächter, supra note 27 (arguing that participants have fairness preferences that lead them to punish even if it were individually rational to refrain from punishing). 
counter-punishment. ${ }^{30}$ Just the fear that punished participants might retaliate significantly reduces the willingness to sanction free-riders.

\section{Climate change as an example: additional challenges}

In the context of climate change, the incentive structure is not the only obstacle to effective mitigation. Instead, there are several additional challenges. First, there is a discounting effect. Human beings usually value future utility less than their present utility. ${ }^{31}$ From an individual perspective, it is rational to focus more on the present utility than on the utility in five or ten years, because there is a slight (or, depending on the age, not so slight) probability that one might not be alive anymore. From a social perspective, however, discounting should play a less prominent role. Even if certain individuals have died, it is unlikely that this will affect the society as a whole, as the deceased are replaced by the newly-born. In the discussion on climate change, discounting is a significant factor. The costs caused by climate change will increase over the coming years and decades. However, the costs of measures to combat climate change have to be borne now. For this reason, societies may be reluctant to undertake measures that will only reap benefits in several years or even decades.

Second, the costs of climate change are distributed asymmetrically. ${ }^{32}$ Coastal regions and regions with a low altitude above sea level will suffer first. China, Europe, and the United States, the principal originators of climate change, may be reluctant to adopt measures for climate protection if the main effects of climate change are first experienced in developing countries, such as Bangladesh or the Comoros. ${ }^{33}$ This example shows that combating climate change involves difficult distributive issues. Who should pay what for saving the climate? Large distributive effects change the incentives for certain individual actors to contribute to a public good. ${ }^{34}$ In our case, it makes the voluntary protection of the climate even more unlikely. $^{35}$

Finally, there is another distributive issue. The discussion on the reduction of greenhouse gases usually includes proposals that countries have to reduce their emissions by a certain degree. The starting point for the calculation of these reduction targets is the current level of emissions. However, richer countries generally have a higher level of emissions and thus benefit

30 Nikos Nikiforakis, Punishment and counter-punishment in public good games: Can we really govern ourselves?, 92 J. PUBL. ECON. 91 (2008).

31 See Marco Percoco \& Peter Nijkamp, Estimating individual rates of discount: a meta-analysis, 16 APPL. ECON. LETTERS 1235 (2009).

32 See Niels Petersen, The Role of Consent and Uncertainty in the Formation of Customary International Law, in REeXAmining Customary InTERnATIONL LAW (Brian Lepard ed., forthcoming 2015). See also George Norman \& Joel P. Trachtman, The Customary International Law Game, 99 AM. J. INT'L L. 541, 554 (2005); Bradley \& Gulati, supra note 1, at 265 generally on the challenge of asymmetry and heterogeneity.

33 See Freeman \& Guzman, supra note 3, at 1594.

34 See Theodore Bergstrom, Lawrence Blume \& Hal Varian, On the Private Provision of Public Goods, 29 J. PUBL. ECON. 25 (1986).

35 See Todd Sandler, Global Collective Action 221-25 (2004) (arguing that the unequal distribution of consequences is the main obstacle to global collective action in mitigating climate change). 
from such a system. ${ }^{36}$ Therefore, developing countries fear that their development could be hampered by emission reduction targets. This is today the most hotly contested point in the negotiations under the UNFCCC. ${ }^{37}$ The result of this dispute was the invention of the principle of Common But Differentiated Responsibility. ${ }^{38}$ However, until there is agreement on how to operationalize this principle, it is mere lip service that does not contribute to finding a solution to the distributional problem of who bears the costs for mitigating climate change.

\section{Public Goods and the Formation of Customary International Law}

In this section, we will take a closer look at the likelihood that norms of customary international law emerging that protect global public goods. Traditionally, scholars dealing with the formation of customary law examine patterns of state practice: Under which conditions is it likely that states coordinate on an equilibrium that leads to the emergence of a new customary norm? ${ }^{39}$ However, the analysis of state practice may not be the only way of identifying a customary norm. In international legal scholarship, there is a strong tendency that observes and advocates a "modern" approach to identifying customary law. ${ }^{40}$ We will look at two different versions of alternative methods and their potential to contribute to the protection of global public goods. On the one hand, we will examine an approach that tries to include some kind of moral element into the identification process. On the other hand, we will analyze elements of lawmaking in the jurisprudence of the International Court of Justice (ICJ).

36 Brunnée \& Toope, supra note 4, at 127-28.

37 See Daniel Bodansky, The Copenhagen Climate Change Conference: A Postmortem, 104 AM. J. INT'L L. 230, 232 (2010) ("Although the U.S.-EU negotiations were always difficult [...] the split between the United States and the European Union pales in comparison to the gulf between developed and developing countries”); Lavanya Rajamani, The Cancun Climate Agreements: Reading the Text, Subtext and Tea Leaves, 60 INT'L \& COMP. L. Q. 499 (2011).

38 On this principle, see Paul G. Harris, Common But Differentiated Responsibility: The Kyoto Protocol and United States Policy, 7 N.Y.U. EnVTL. L.J. 27 (1999); Duncan French, Developing States and International Environmental Law: The Importance of Differentiated Responsibilities, 49 INT'L \& COMP. L. Q. 35 (2000); Graham Mayeda, Where should Johannesburg Take Us? - Ethical and Legal Approaches to Sustainable Development in the Context of International Environmental Law, 15 COLO. J. INT'L ENVTL. L. \& POL'y 29 (2004); Christopher D. Stone, Common But Differentiated Responsibilities in International Law, 98 AM. J. INT'L L. 276 (2004).

39 The classic contribution in this sense is Jack L. Goldsmith \& Eric A. Posner, A Theory of Customary International Law, 66 U. CHI. L. REV. 1113 (1999). See also Mark A. Chinen, Game Theory and Customary International Law: A Response to Professors Goldsmith and Posner, 23 MicH. J. INT'L L. 143 (2001); Edward T. Swaine, Rational Custom, 52 Duke L. J. 559 (2002).

40 See, e.g., Anthea Elizabeth Roberts, Traditional and Modern Approaches to Customary International Law: A Reconciliation, 95 AM. J. INT’L L. 757 (2001); John Tasioulas, Customary international law and the quest for global justice, in THE NATURE OF CUSTOMARY LAW 307 (Amanda Perreau-Saussine \& James Bernard Murphy eds., 2007); William Schabas, Customary Law or “Judge-Made” Law: Judicial Creativity at the UN Criminal Tribunals, in THE LEgAL REgIME OF THE INTERNATIONAL CRIMINAL Court. Essays in Honour of Professor IgOR Blishchenko 77 (José Doria, Hans-Peter Gasser \& M. Cherif Bassiouni eds., 2009); Roozbeh B. Baker, Customary International Law in the 21st Centiry: Old Challenges and New Debates, 21 EuR. J. INT'L L. 173 (2010); Rudolf Geiger, Customary International Law in the Jurisprudence of the International Court of Justice: A Critical Appraisal, in FROM BILATERALISM TO COMMUNITY INTEREST: ESSAYS IN HONOUR OF BRUNO SimMA 673 (Ulrich Fastenrath et al. eds., 2011). 


\section{Customary law and patterns of state practice}

It is beyond doubt that cooperation between different individuals is possible even if each participant has short-term incentives to defect. The tension between socially optimal and individually rational behavior is best expressed in the prisoner's dilemma. ${ }^{41}$ In a one-shot prisoner's dilemma, each individual is better off if she defects, even though cooperation is the socially optimal strategy. If the game is played repeatedly for an indefinite number of times, participants in a bilateral prisoner's dilemma situation have incentives to cooperate in order to induce cooperation from the counterpart. ${ }^{42}$ Nevertheless, it is unclear whether cooperation can also be maintained in multilateral prisoner's dilemma situations.

According to Jack Goldsmith and Eric Posner, cooperation is virtually impossible in multilateral settings. ${ }^{43}$ While reciprocity is the driving force for cooperation in the bilateral situation, it is, they argue, much less effective in a multilateral setting: If one state overexploits a common pool resource, the reciprocal overuse by all other states is no effective response to protect the resource. ${ }^{44}$ Furthermore, the costs of monitoring increase with the number of states, which could lead to more undetected free-riding. ${ }^{45}$

This analysis is based on the assumption that states in international relations are only motivated by self-interest. If all states were potential free-riders, multilateral cooperation would indeed be difficult to sustain. However, the experimental evidence suggests that most individuals are conditional cooperators. ${ }^{46}$ We certainly have to be cautious to extrapolate from individual behavior to the conduct of state officials. There might be a selection effect that uncooperative individuals are more likely to assume public office. Furthermore, in democratic states, incentives to cater to the national electorate might also lead to more uncooperative conduct. However, there are at least serious doubts whether the assumption that states are

41 A linear public good is characterized as a prisoner's dilemma of more than two players and a continuous space of action. However, the provision of public goods does not necessarily imply the incentive structure of a multiplayer prisoner's dilemma. See Holzinger, supra note 9; Stefan Magen, Game Theory and Collective Goods, in ECONOMIC METHODS FOR LAWYERS (Emanuel Towfigh \& Niels Petersen eds., forthcoming 2015).

42 See Goldsmith \& Posner, supra note 39, at 1125-27; Norman \& Trachtman, supra note 32, at 565-66. Technically, a repeated prisoner's dilemma has multiple Nash equilibria. According to the so-called folk theorem, we can expect cooperation in such situations if the players have a sufficiently low discount-rate. See Magen, supra note 41.

43 Goldsmith \& Posner, supra note 39, at 1129-30. But see also Robert Pahre, Multilateral Cooperation in an Iterated Prisoner's Dilemma, 38 J. ConfL. RESOLUTiOn 326 (1994) (arguing that multilateral cooperation can, in some cases of the iterated prisoner's dilemma, be even more effective than bilateral cooperation).

44 Goldsmith \& Posner, supra note 39, at 1129-30.

45 Id., at 1130. This argumentation was partly refuted by George Norman and Joel Trachtman, see Norman \& Trachtman, supra note 32. They point out that reciprocity must not be impossible in multilateral settings (id., at 556-59). This is particularly the case if multilateral obligations can be divided into multiple bilateral obligations. But even in situations involving the protection of a public good, cooperation is even if less likely - not impossible. Norman and Trachtman highlight reputation effects and possibilities of punishing defecting states by suspending cooperation in other fields (id., at 567). 
free-riders is plausible per se. If we assume that at least some states are conditional cooperators, cooperation is more easily achievable. ${ }^{47}$

Furthermore, it is important to keep in mind the asymmetric importance of different states for the maintenance of a public good or a common pool resource. There are usually certain core states whose cooperation is more important for the protection of a global public good than the conduct of other states. ${ }^{48}$ If China, the United States, and the European Union are responsible for the great majority of greenhouse gas emissions, any cooperative arrangements to reduce emissions have to include these actors. If states are conditional cooperators, their willingness to reduce greenhouse gas emissions will crucially depend on the cooperation of the principal originators. ${ }^{49}$ Their efforts to reduce emissions have little effect on the global climate if the mainly responsible states do not contribute.

By contrast, this also means that not every defection severely undermines overall cooperation. The defection of non-lead actors will have less of an impact than the defection of leading states. ${ }^{50}$ The good news is therefore that only the cooperation of a small number of core states is vital to sustain a high level of protection. ${ }^{51}$ An example of how such cooperation could work is the 2009 Copenhagen Accord, which was reached by the Heads of States of 28 member states of the UNFCCC, including all major emitters. ${ }^{52}$ Even though the Copenhagen Accord failed to achieve a formal status under the Framework Convention, it is often considered to be a promising step in the evolution of the climate regime. ${ }^{53}$ Still, the accord focuses more on self-selected targets, actions, and procedural obligations. It is therefore far from being a break-through in establishing cooperation for mitigating climate change.

\section{Moral interpretations of customary law}

Focusing on patterns of state practice is not the only way of identifying rules of customary law. States often have incentives to pursue short-term interests even though such conduct en-

47 See Engel \& Kurschilgen, supra note 16, at 585-88 (who show that the mere normativity of cooperation has a positive effect on contributions to public goods).

48 See Pierre-Hugues Verdier \& Erik Voeten, Precedent, Custom and Change in Customary International Law: An Explanatory Theory, 108 AM. J. INT’L L. 389, 404 (2014).

49 For experimental evidence that the example of stronger participants in a public goods game significantly affects the behavior of other participants, see Andreas Glöckner et al., Leading with(out) Sacrifice? A Public Goods Experiment with a Priviledged Player, 49 ECON. INQUIRY 591 (2011).

50 However, this might lead some states to free-ride if they know that their deviant conduct does not affect overall cooperation: They would reap the benefits of the cooperation of the lead actors while not bearing the costs, see Joel P. Trachtman, The Obsolescence of Customaty International Law, in this volume.

51 See Krisch, supra note 2, at 16. See also Victor, supra note 5, at 242-43 (advocating the formation of small clubs as a starting point for international commitments); Robin Eckersley, Moving Forward in the Climate Negotiations: Multilateralism or Minilateralism, 12 GLOB. ENV. POL. 24 (2012) (advocating an inclusive "minilateralism" for the climate change negotiations); Sandler, supra note 35, at 217 (noting that the concentration of key emitters was one of the success factors for international efforts to combat CFC emissions and to protect the ozone layer).

52 UNFCCC, Decision 2/CP.15, 'Copenhagen Accord' (March 30, 2010), UN Doc FCCC/CP/2009/11/ Add.1 (Copenhagen Accord).

53 Duncan French \& Lavanya Rajamani, Climate Change and International Environmental Law: Musings on a Journey to Somewhere, 25 J. ENV. L. 437, 447 (2013). 
tails significant social costs and may run counter to the long-term interest of the state. ${ }^{54}$ This divergence between short-term and long-term interests often becomes manifest if declarations and resolutions are adopted by states in multilateral settings and express desirable social goals that are not backed by a corresponding state practice. This has led many scholars to propose approaches to customary law that concentrate on opinio iuris or moral principles instead of state practice. $^{55}$

Some authors have proposed to renounce state practice as a constitutive element of customary international law and to regard it merely as an indication for the existence of an opinio iuris. ${ }^{56}$ Others want to dispense with practice at least for those principles that supposedly reflect the consensus of the international community ${ }^{57}$ or fundamental moral principles. ${ }^{58}$ Bruno Simma and Philip Alston have proposed to concede the status of general principles to fundamental human rights norms. ${ }^{59}$ Finally, there are approaches that do not totally dispense with state practice, but aim to diminish the importance of state practice in cases where we can identify a strong and consistent opinio iuris, ${ }^{60}$ or which relate to norms of a considerable moral importance. ${ }^{61}$ While these approaches primarily try to justify the normative character of human rights norms because of their moral importance, they could equally be applied to the protection of public goods. ${ }^{62}$ In cases where there is a divergence between short-term incentives of states and long-term social benefits, we could identify customary rules rather based on opinio iuris than on actual state practice.

54 See Vincy Fon \& Francesco Parisi, International Customary Law and Articulation Theories: An Economic Analysis, 2 InT'L L. \& MGMT. Rev. 201, 214 (2006), who propose to put a stronger emphasis on declared state intentions instead of actual practice in such circumstances.

55 These approaches have often been coined with the term "modern approaches" to customary law. See Michael Wood, First report on formation and evidence of customary international law, UN Doc. A/CN.4/663 (May 17, 2003), para. 98 with further references.

56 See Bin Cheng, United Nations Resolutions on Outer Space: “Instant” International Customary Law?, 5 INDIAN J. INT'L L. 23, 35-40 (1965); Bin Cheng, On the Nature and Sources of International Law, in INTERnational Law. Teaching AND Practice 203 (Bin Cheng ed., 1982); Andrew T. Guzman, Saving Customary International Law, 27 MiCH. J. INT’L L. 115 (2005); BRIAN D. LEPARD, CuSTOMARY INTERnational Law. A New Theory With Practical Applications 98 (2010); Curtis A. Bradley, Customary International Law Adjudication as Common Law Adjudication, in this volume; Brian D. Lepard, Customary International Law as a Dynamic Process, in this volume. See also John Tasioulas, Custom, Consent, and Human Rights, in this volume (arguing that opinio iuris can establish a customary norm in the absence of state practice).

57 Louis B. Sohn, The Human Rights Law of the Charter, 12 TEX. INT'L L. J. 129, 133 (1977).

58 Fernando R. Tesón, Two Mistakes about Democracy, 92 ASIL ProcEEDINGs 126, 127 (1998).

59 Bruno Simma \& Philip Alston, The Sources of Human Rights Law: Custom, Jus Cogens, and General Principles, 12 AustL. YB. INT'L L. 82 (1992). Similarly Oscar Schachter, New Custom: Power, opinio iuris and contrary practice, in THEORY OF INTERNATIONAL LAW AT THE THRESHOLD OF THE 21ST CENTURY: ESSAYS IN HONOUR OF KRZYSZTOF SKUBISZEWSKI 531, 539 (Jerzy Makarczyk ed., 1996); Albert Bleckmann, Zur originären Entstehung gewohnheitsrechtlicher Menschenrerchtsnormen, in MENSCHENRECHTSSCHUTZ DURCH GEWOHNHEITSRECHT 29, 42-43 (Eckart Klein ed., 2002). See also Niels Petersen, Customary Law without Custom? - Rules, Principles, and the Role of State Practice in International Norm Creation, 23 AM. U. INT'L L. REV. 275, 303-05 (2008), who proposes to recur to general principles in the case of norms relating to public goods and to human rights.

60 See Frederic L. Kirgis, Custom on a Sliding Scale, 81 AM. J. INT’L L. 146 (1987).

61 See John Tasioulas, In Defence of Relative Normativity: Communitarian Values and the Nicaragua Case, 16 OXFORD J. LEGAL STUD. 85 (1996).

62 See Petersen, supra note 59, at 303-05. 
There are two objections against such an approach. Two decades ago, Martti Koskenniemi warned that an overly idealist interpretation of international law easily gets caught in a utopian trap, which deprives the legal norm of any practical significance. ${ }^{63}$ According to this position, customary rules not reflected in state practice are nothing more than ineffective pipe dreams of international lawyers. Second, even if we all agree that the protection of the atmosphere is an important goal, it is unclear how this goal should be implemented as implementation strategies usually involve complex compromises. ${ }^{64}$ Strategies to combat climate change or to protect fish stocks include the reduction of a certain activity without renouncing it completely. States agree to reduce their carbon emissions or their fishing quotas, but they do not set them to zero.

While these objections have some merits, they underestimate the dynamic nature of the process of legal interpretation. It is often difficult to distinguish between the processes of lawmaking and law interpretation. Every dispute about the content of a rule is, at the same time, also a process of developing this legal rule. ${ }^{65}$ Monica Hakimi has shown in her contribution to this volume how claims about customary norms can change the expectations of other actors regarding the content of these rules. ${ }^{66}$ An interpretation of customary norms that relies on an opinio iuris not supported by state practice may thus be a factor of changing this rule and thus state conduct in the long term. ${ }^{67}$

Furthermore, customary norms gain in precision if they originate from soft law instruments. It has long been recognized that certain soft law instruments, such as resolutions of the UN General Assembly, may be an expression of opinio iuris. ${ }^{68}$ In the context of climate change, the already mentioned Copenhagen Accord might be an example of a soft law instrument expressing an opinio iuris of the participating states. The targets agreed upon in the accord can lead to the formation of expectations by other states with regard to climate change mitigation targets.

Nevertheless, even under the conditions developed in the last two paragraphs, the role of customary law is limited. On the one hand, it is dependent on the existence of soft law instruments. Up to date, the scope of soft law instruments in the field of climate change is limited. On the other hand, one may ask whether qualifying a soft law instrument as customary law adds anything to the normative force of soft law. In situations without a dispute resolution mechanism, the difference is probably marginal. The soft law instrument itself already creates

63 See Martti Koskenniemi, The Politics of International Law, 1 EUR. J. INT'L L. 4 (1990).

64 See also Trachtman, supra note 50 (on the lack of sufficient precision of customary law).

65 See Wayne Sandholtz \& Alec Stone Sweet, Law, politics, and international governance, in THE PoLITICS OF INTERNATIONAL LAW 238 (Christian Reus-Smit ed., 2004); Wayne Sandholtz, Dynamics of International Norm Change: Rules against Wartime Plunder, 14 EUR. J. INT’L REL. 101 (2008).

66 Monica Hakimi, Custom's Process and Method: Lessons from Humanitarian Law, in this volume.

67 Niels Petersen, Rational Choice or Deliberation? - Customary International Law between Coordination and Constitutionalization, 165 JITE 71, 81-82 (2009).

68 Alan Boyle \& Christine Chinkin, The MaKing of International LaW 212 (2007); Laurence R. Helfer \& Ingrid Wuerth, Customary International Law in the Age of Soft Law (Working Paper, 2014); Jan Wouters \& Linda Hamid, Custom and Informal International Lawmaking, in this volume. 
normative expectations. It is hard to see how calling these norms customary norms makes any difference. However, there may be a difference in situations in which we have a dispute settlement system. This constellation will be addressed more in detail in the following section.

\section{Judicial lawmaking}

It is a commonplace today that judicial decisions are not exclusively derived from legal norms. Instead, the social, cultural, and political background of judges influences their decision-making, as do strategic considerations. ${ }^{69}$ Courts not only find law, they also make law. ${ }^{70}$ The ICJ is no exception in this respect. ${ }^{71}$ Because of its vagueness, customary international law seems to be particularly prone to judicial lawmaking. If we analyze the approach of the ICJ to the identification of customary international law, it seems indeed that the jurisprudence is, at least in part, driven by strategic considerations. ${ }^{72}$ Consequently, this section will analyze whether the ICJ might help the cause of mitigating global climate change by using its strategic discretion in order to identify customary norms favorable to the protection of the global climate.

Customary law often has the function to fill the gaps left by treaty law. According to conventional wisdom, situations that are not governed by legal rules are governed by the Lotus principle. ${ }^{73}$ In Lotus, the Permanent Court of International Justice basically established a freedom of action for states. ${ }^{74}$ According to the Lotus principle, states are only bound by legal rules to which they have consented. In some situations, however, the Lotus principle does not help us to resolve a dispute between states because the dispute is precisely about competing sovereignty claims of states. ${ }^{75}$

In such cases, the ICJ often recurs to pragmatic strategies of identifying customary norms. In some judgments, the Court refers to principles of equity. ${ }^{76}$ The most famous example is probably the North Sea Continental Shelf case. ${ }^{77}$ In North Sea Continental Shelf, the Court had to

69 There is a controversial discussion on which factors influence judicial decision-making on the US Supreme Court. However, there seems to be consensus that legal methods are not the only factor determining the results of judgments. On the different positions, see Jeffrey A. Segal \& Albert D. Cover, Ideological Values and the Votes of U.S. Supreme Court Justices, 83 AM. PoL. SC. REV. 557 (1989); Tracey E. George \& Lee Epstein, On the Nature of Supreme Court Decision Making, 86 AM. PoL. Sc. REV. 323 (1992); Mark J. Richards \& Herbert M. Kritzer, Jurisprudential Regimes in Supreme Court Decision Making, 96 AM. Pol. Sc. REV. 305 (2002); Thomas Brennan, Lee Epstein \& Nancy Staudt, The Political Economy of Judging, 93 Minn. L. ReV. 1503 (2009); Michael A. BAiley \& Forrest Maltzman, The Constrained Court: LAW, Politics, AND THE DeCisions Justices MaKe (2011).

70 Armin von Bogdandy \& Ingo Venzke, Beyond Dispute: International Judicial Institutions as Lawmakers, in INTERNATIONAL JUDICIAL LAWMAKING 3 (Armin von Bogdandy \& Ingo Venzke eds., 2012).

71 Niels Petersen, Lawmaking by the International Court of Justice, 12 GERMAN L. J. 1295 (2011).

72 Similarly Bradley, supra note 56.

73 Lotus (Fr. v. Turk.), 1927 P.C.I.J. (ser. A) No. 10, at 18 (Sept. 7).

74 See Albert Bleckmann, Das Souveränitätsprinzip im Völkerrecht, 23 AVR 450, 464-68 (1985).

75 Martti Koskenniemi, From Apology to Utopia. The Structure of the International Legal ARGUMENT 257 (2005).

76 See Emily Kadens \& Ernest A. Young, How Customary is Customary International Law?, 54 WM. \& MARY L. REV. 885, 911 (2013).

77 North Sea Continental Shelf (F.R.G. v. Denmark, F.R.G. v. the Netherlands), 1969 I.C.J. 3 (Feb. 20). 
deal with the delimitation of continental shelf areas between Germany and Denmark as well as the Netherlands. The Court found that there was no customary rule supported by sufficient state practice governing the case. The predominant equidistance principle had not been sufficiently supported by state practice and opinio iuris. ${ }^{78}$ In order to resolve the case, the Court referred to equitable considerations. ${ }^{79}$ It imposed a procedural obligation to negotiate on the parties and gave some directions for these negotiations.

In other cases, the Court relies on treaties or resolutions of international organizations as indicators for customary international law. ${ }^{80}$ This predominantly concerns the secondary rules of international law, such as the rules on treaty interpretation, where the ICJ frequently refers to the Vienna Convention on the Law of Treaties, ${ }^{81}$ or the norms regarding state responsibility, which are usually identified through reference to the ILC Articles on State Responsibility. ${ }^{82}$ In some cases, however, the Court also refers to treaties in order to establish substantive norms of international law. In Nicaragua, the ICJ relied on the UN Charter to establish a customary prohibition of the use of force in international relations. ${ }^{83}$ In its advisory opinion on the use of nuclear weapons, the Court stated that the rules of international humanitarian law established in the Hague and Geneva Conventions form part of customary international law. ${ }^{84}$ Finally, in the dispute between Belgium and Senegal on the extradition of the former Chadian president Hissène Habré, the Court mainly referred to treaty law to identify a customary prohibition of torture. $^{85}$

These examples show that the ICJ sometimes utilizes its discretion to "identify" customary norms without proving a consistent state practice. However, the value of this judicial practice for the protection of global public goods is rather limited. Appeals to equity as in the Northern Continental Shelf judgments rarely have a precedential value that transgresses the individual case because they are usually fitted to the circumstances of the case in question. ${ }^{86}$

The main source of identifying customary law seems to be the reference to treaties and to UN General Assembly resolutions. ${ }^{87}$ Basing the identification of custom on treaties or soft law

$78 \quad$ Id., at 982.

79 Id., at 9 ๆ 83-99.

80 Alberto Alvarez-Jiménez, Methods for the Identification of Customary International Law in the International Court of Justice's Jurisprudence: 2000-2009, 60 INT’L \& COMP. L. Q. 681, 690 (2011). See also the empirical analysis of Mitu Gulati, Customary International Law: How do Courts Do It?, in this volume, according to whom treaties are the main evidence for custom in international adjudication.

81 See, e.g., Application of the Convention on the Prevention and Punishment of the Crime of Genocide (Bosnia v. Serbia), 2007 I.C.J. 43, at 160 (Feb. 26); Navigational and Related Rights (Costa Rica v. Nicaragua), 2009 I.C.J. 213, at 47 (July 13); Pulp Mills on the River Uruguay (Argentina v. Uruguay), 2010 I.C.J. 14, at ๆๆ 64-65, 121, 145 (Apr. 20); Questions relating to the Obligation to Prosecute or Extradite (Belgium v. Senegal), 2012 I.C.J. 422, at 1113 (July 20).

82 See, e.g., Bosnia v. Serbia, supra note 81, at 9 ๆ 385, 388, 398, 420; Jurisdictional Immunities of the State (Germany v. Italy), 2012 I.C.J. 99, at 58 (Feb. 3).

83 Military and Paramilitary Activities in and against Nicaragua (Nicaragua v. U.S.), 1986 I.C.J. 14, at 9181 (June 27).

84 Legality of the Threat or Use of Nuclear Weapons, 1996 I.C.J. 226, at 979 (July 8).

85 Belgium v. Senegal, supra note 81, at 999.

86 Kadens \& Young, supra note 76, at 912.

87 See Gulati, supra note 80. 
may have three practical consequences. First, it allows the judges to apply a norm contained in a treaty even in cases in which it does not have jurisdiction over the treaty. Second, the customary norm may be used in order to extend treaty obligations to states that have not ratified a specific treaty. Third, it may give normative force to soft law instruments. The first two options presuppose the existence of near-universal treaties. At least, with regard to the protection of the atmosphere, such a prospect is still rather distant. The ICJ might play a useful role in stabilizing expectations with regard to international soft law. However, the problem here is that the Court will often not have jurisdiction over the corresponding issues.

\section{Public Goods and the Unilateral Extension of Authority}

The analysis in the previous section has shown that the prospect for protecting global public goods through customary international law is not overly positive. ${ }^{88}$ In this section, I will argue that the most promising avenue is the extension of authority through initially unilateral actions. ${ }^{89}$ Joel Trachtman has pointed out that most rules of international law are about the allocation of authority. ${ }^{90}$ He argues that the primary function of jurisdictional rules is the internalization of externalities. ${ }^{91}$ The problem of global public goods is that all states have shared authority about their maintenance and protection so that externalities cannot easily be internalized.

One example of how the initially unilateral extension of authority might protect public goods and common pool resources is the development of the protection of fish stocks. ${ }^{92}$ While it is socially optimal not to overexploit the existing fish stocks, every state has incentives to freeride. ${ }^{93}$ States tried to combat these exploitation incentives by progressively extending their jurisdiction of fishing rights. During the negotiations of the 1958 Geneva Conference on the Law of the Sea, participating states discussed whether to establish a twelve-mile exclusive fishing zone that extended six miles beyond the six-mile territorial sea. The proposal failed by one vote. However, soon after the conference, several states started to issue declarations claiming a twelve-mile exclusive fishing zone. ${ }^{94}$ The development did not stop there. Famous is the case of Iceland, which unilaterally extended its exclusive fishing zone to 50 nautical miles - an act that was challenged by Germany and the United Kingdom before the International Court of Justice. ${ }^{95}$

88 Similarly Bradley \& Gulati, supra note 1, at 264-66.

89 See also Daniel Bodansky, What's So Bad about Unilateral Action to Protect the Environment?, 11 EUR. J. INT'L L. 339, 343-47 (2000) (pointing out the importance of unilateralism in lawmaking concerning international environmental law).

$90 \quad$ Norman \& Trachtman, supra note 32, at 562.

91 Joel P. TRACHTMAn, THE ECONOMIC STRUCTURE OF INTERNATIONAL LAW 28-29 (2008).

92 See also Andrew T. Guzman, Against Consent, 52 VA. J. INT’L L. 747, 769-772 (2012).

93 Guzman, supra note 92, at 768.

94 LOTHAR GÜNDLING, DIE 200 SEEMEILEN-WIRTSCHAFTSZONE 22 (1983).

95 See Fisheries Jurisdiction (U.K. v. Iceland), 1974 I.C.J. 3 (July 25); Fisheries Jurisdiction (F.R.G. v. Iceland), 1974 I.C.J. 175 (July 25). 
However, Iceland's conduct was no exception. A survey of the UN Food and Agricultural Organization (FAO) in 1969 showed that, while most states claimed an exclusive fishing zone of 12 nautical miles, some countries had extended their exclusive fishing zone up to 200 nautical miles. ${ }^{96}$ This development picked up speed in the early 1970s. In 1970 and 1972, several Latin American countries adopted declarations in which they claimed exclusive rights of jurisdiction within 200 nautical miles from their coast. ${ }^{97}$ In 1973, the Organisation of African Unity (OAU), the precursor to the African Union, declared that African states recognized the right of each coastal state to establish an exclusive economic zone not exceeding 200 nautical miles. $^{98}$

This development was also taken up in Europe. Even though the ICJ had confirmed the position of the UK and Germany in the dispute with Iceland on the extent of exclusive fishing zone, ${ }^{99}$ Iceland did not comply with the judgment. ${ }^{100}$ On the contrary, it even extended its exclusive fishing zone to 200 nautical miles in July 1975. In 1976, the European Community followed suit. In a Council resolution, it asked all member states to extend their exclusive fishing zones to 200 miles. ${ }^{101}$ This position was finally confirmed in the United Nations Convention on the Law of the Sea from 1982, which recognized the right of all coastal states to establish a 200-mile exclusive economic zone. ${ }^{102}$

This extension of the fisheries jurisdiction contributed to the protection of fish stocks. In order to protect its own national fisheries, every state had incentives to establish and implement quota systems within its own jurisdiction - a mode of protection that could not have been implemented in a system of shared authority. What helped the cause was the distributional impact of the extension of the fisheries zone. ${ }^{103}$ States dependent on their coastal fisheries had particularly strong incentives to extend their fisheries jurisdiction. ${ }^{104}$ The technological development after the Second World War allowed technologically advanced states to exploit fish stocks at greater distance from the coast. However, as fish stocks migrate, this significantly impacted the coastal fisheries. It is thus not surprising that the development of extending the fisheries jurisdiction first originated in developing countries with a significant coastal subsist-

96 F.A.O., Limits and Status of the Territorial Sea, Exclusive Fishing Zones, Fishery Conservation Zones and the Continental Shelf, 8 INT'L LEg. MATERIALS 516 (1969).

97 See Montevideo Declaration on the Law of the Sea (May 8, 1970), 64 AM. J. INT’L. L. 1021 (1970); Declaration of Latin American States on the Law of the Sea (Aug. 8, 1970), reprinted in: 1 New DiRECTIONS IN THE LAW OF the SEA 237 (S. Houston Lay, Robin R. Churchill \& Myron H. Nordquist eds., 1973); Declaration of Santo Domingo (June 9, 1972), reprinted in: 1 New DiRECTIONS IN THE LAW OF THE SEA 247 (S. Houston Lay, Robin R. Churchill \& Myron H. Nordquist eds., 1973).

98 Declaration of the Organization of African Unity on the Issues of the Law of the Sea (July 19, 1974), U.N. Doc. A/CONF.62/33.

99 Fisheries Jurisdiction, supra note 95.

100 Constanze Schulte, Compliance with Decisions of the International Court of Justice 151 (2004).

101 European Communities, Council Resolution on Certain External Aspects of the Creation of a 200-MileFishing Zone in the Community with Effect from 1 January 1977 (Nov. 3, 1976), 15 INT’L LEG. MATERIALS 1425 (1976). United Nations Convention on the Law of the Sea, Art. 57 (Dec. 10, 1982), 1833 U.N.T.S. 3.

Verdier \& Voeten, supra note 48, at 406. 
ence fishing industry. ${ }^{105}$ At some point the technologically advanced states had to follow suit. Opposing the extension of fishing zones was too costly. ${ }^{106}$ Consequently, they wanted to reap at least the benefits of extending their own fishing zones.

The protection of fish stocks through the extension of the fisheries jurisdiction is certainly not perfect. ${ }^{107}$ Notably, fish stocks on the high seas beyond the 200-mile exclusive economic zone are still unprotected. Furthermore, the protection depends on countries adopting effective schemes within their own jurisdiction. Nevertheless, the example shows how at least some level of protection for global public goods can be achieved through the initially unilateral extension of authority.

Does this also entail lessons for the protection of the global climate? Prima facie, the situation is more complex. Fishing still has a partly local component. Even though fish stocks migrate, the fishing industry on the east coast of the United States is largely unaffected by what happens in the Indian Ocean. Therefore, if the US establishes an effective scheme to protect fish stocks, this scheme has certain positive external effects. But the US will reap the greatest benefits. By contrast, the locality of the emission is irrelevant for the climate. ${ }^{108}$ Sea levels in Bangladesh will continue to rise regardless of whether the emissions stem from South Asia or from Western Europe. For this reason, if the EU adopts measures to mitigate climate change, the positive effect will not necessarily be the strongest in Europe.

Nevertheless, a unilateral extension of authority that could at some point lead to the emergence of a customary rule does not seem impossible. ${ }^{109}$ The primary vehicles of internalizing external effects that are generated through the pollution of the atmosphere are the taxation of polluting conduct or trading schemes that require emission permits for polluting activities. If a country wants to establish such a system unilaterally, it has to fear detrimental effects for its economy. ${ }^{110}$ Emission taxes or the requirement of emission permits impose additional costs on the domestic industries and thus reduce their competitiveness on global markets.

One solution could be to include foreign producers or service providers into the taxing or trading scheme. It is sometimes argued that such an extraterritorial extension of taxing or trading schemes could violate the principle of the territoriality of jurisdiction. When the European Union extended the EU Emissions Trading System (ETS) to aircraft operators, it also required non-EU airlines to purchase emission permits for flights to and from the European Union. ${ }^{111}$ These permits were required for the whole distance of the flight even if only part of it took

105 Petersen, supra note 71, at 1315.

106 Verdier \& Voeten, supra note 48, at 407.

107 Guzman, supra note 92, at 771.

108 Victor, supra note 5, at 4.

109 See also Elinor Ostrom, Polycentric systems for coping with collective action and global environmental change, 20 GLOB. ENV. CHANGE 550 (2010) (advocating a polycentric approach for mitigating climate change).

110 Freeman \& Guzman, supra note 3, at 1594.

111 See Directive 2008/101/EC of the European Parliament and the European Council (Nov. 19, 2008), 2009 O.J. L $8 / 3$. 
place over European territory. This regulation was challenged by the Air Transport Association of America (ATAA) and some major US airlines before the European Court of Justice (ECJ). ${ }^{112}$ The applicants claimed that the regulation violated the customary principle of territoriality. The European Court refuted the argument. In its view, the decisive connection for the effects of the regulation was the arrival at or departure from a European airport. ${ }^{113}$

Even if one accepts the view of the ECJ, such an inclusion of transboundary transport services is in need of coordination in order to avoid the service carrier being charged several times. The EU attributes the responsibility for charging the air carrier to the departure state. However, if the departure state does not apprehend its responsibility to include air carriers in a scheme for the mitigation of climate change, the EU reserves the right to step in. ${ }^{114}$ While foreign service providers can thus usually be directly included in an emission trading system, such an inclusion is not possible for foreign producers. But countries adopting a tax- or tradebased emission reduction scheme could levy an environmental tax on imports from countries, which do not have a comparable emission reduction scheme. ${ }^{115}$

However, the judgment of the ECJ did not end the controversy. There are several states that oppose the attempt of the EU to include international routes of foreign airlines in the ETS. Such unlikely allies as Russia, China, India, and the United States threatened retaliatory measures. ${ }^{116}$ Arguably, the extent of the principle of territorial jurisdiction is thus unclear, to say the least. The regulation of the EU can be seen as an attempt to push the development into a specific direction, i.e., to change an existing norm of customary international law by extending the territoriality principle.

The result of this controversy is still open. The resistance against the inclusion of international air traffic in the ETS has induced the EU to postpone the inclusion of flights to and from nonEU member countries in the EU ETS for four years after the International Civil Aviation Organization (ICAO) agreed to propose a global, market-based emission reduction mechanism by 2016 .

But it is important to note that there was also retaliation when countries initially started to extend their exclusive fishing zones. The more countries join the effort to establish effective emission reduction systems, the more costly retaliation will become. As with the fisheries jurisdiction case, there will be a tipping point, ${ }^{117}$ at which resistance has more costs than benefits so that countries have incentives to adopt their own emission reduction schemes because of pure self-interest. If their companies have to pay environmental taxes for the exports into

112 See Case C-366/10, Air Transport Association of America, 2011 E.C.R. I-13755.

113 Id., at paras 121-30.

114 See Joanne Scott \& Lavanya Rajamani, EU Climate Change Unilateralism, 23 EUR. J. INT’L L. 469, 475 (2012).

115 For details of how to design such a border tax, see Stéphanie Monjon \& Philippe Quirion, Addressing leakage in the EU ETS: Border adjustment or output-based allocation?, 70 ECOL. ECON. 1957 (2011).

116 See Scott \& Rajamani, supra note 114, at 473.

117 On this tipping point theory regarding the emergence and change of customary international law, see Verdier \& Voeten, supra note 48. 
the most important markets, so that they do not reap the benefits of low production costs, it may be more rational to establish an own taxation system in order to generate at least some income for the national budget.

The main problem will be to find an actor to initiate the process. In the fish stock example, it was the countries that depend most on their coastal fisheries which had an interest in extending their fisheries jurisdiction. The countries that are most affected by climate change and that would have a strong interest in initiating a process of greenhouse gas reduction probably do not have enough weight - in terms of their share in the global greenhouse gas emissions and their economic strength. The European Union has already established an Emission Trading Scheme. However, the EU ETS has so far been largely ineffective, as economic concerns seem to trump ecological considerations. This will probably not change until environmental concerns rise in the agenda of domestic interest groups.

\section{Conclusion}

The potential of customary international law to protect global public goods is limited. The advantage of customary law over treaty mechanisms is the increased flexibility. Especially in the field of mitigating climate change, some authors have put hope into custom as a remedy when formal treaty negotiations fail. However, the protection of public goods through customary law has its own problems. Economic theory and experimental evidence show that the establishment of public goods through decentralized cooperation is difficult. The most promising avenue for protecting public goods on the global plane is the extension of authority through initially unilateral action. The protection of fish stocks through the initially unilateral extension of the exclusive fishing zone to 200 nautical miles provides a good example for how the protection of public goods through the initially unilateral extension of authority can work. Whether this example entails lessons for the mitigation of climate change remains to be seen. $^{118}$

118 See James Bushnell, Carla Peterman \& Catherine Wolfram, Local Solutions to Global Problems: Climate Change Policies and Regulatory Jurisdiction, 2 REv. ENV. ECON. POL’y 195 (2008); Krisch, supra note 2, at 20 (expressing skepticism with regard to unilateral action to cope with the challenges of climate change). 